Dr. Legrand du Saulle was physician-in-chief at the Special Infirmary connected with the Dépôt of the Prefecture of Police, where he enjoyed a large field of observation. During the Congress of Mental Medicine in Paris, in 1878 , a number of those who attended accompanied him to the Infirmary, and Dr. Legrand du Saulle explained to them the course pursued in Paris, which was in striking contrast with the slip-shod methods practised in London at that time.

The deceased alienist was at one time President of the Sociate Mbdico. Paychologique, of Paris.

\title{
M. BILLOD, M.D.
}

Dr. Billod was formerly Medical Superintendent of the Vaucluse Asylum, a large institution near Paris. He was the author of important memoirs, most of which were collected together several years ago and published in two volumes. His Treatise on Pellagra should be consulted by those studying the subject. His death took place Feb. 26, 1886, at the age of 67.

\section{Appointments.}

Arrd, C., M.B.Aberd., appointed Medical Officer to the East Riding Lunatio Asylum, vice G. T. Broatch, M.B.Fd., resigned.

Dr. T. R. BURKr, late Deputy Inspector-General of Hospitals and Fleets, appointed Assistant Medical Officer, Central Criminal Lunatio Asylum, Dundrum, co. Dublin, vice Mr. Taylor.

JAYrs J. DwYer, L.K.Q.C.P. and L.R.C.S.I., late of the Mullingar Asylum, appointed Medical Superintendent of the District Asylum, Cork, vice Dr. Frames, deceased.

LAW, J. 8., M.D.Ed., appointed Resident Clinical Assistant in the North Riding of Yorkshire Lanatio Asylum, Clifton, Yorks.

LICHrikud, J. W., L.R.C.P.Lond., appointed Resident Clinical Assistant to the Birmingham Borough Asylum, vice J. S. Law, resigned.

Dr. Conorty Norman, appointed Medical Superintendent of the Richmond Asylum, Dublin, vice Dr. Lalor, resigned.

Rigden, Alan, L.R.C.P., M.R.C.S.Lond., appointed Junior Assistant Medical Officer to the Salop and Montgomery Asylum, Shrewsbury, vice P. M. Earle, L. B.C.P., L.R.C.S,Ed., resigned.

EdTard TAYLOR, L.K.Q.C.P. and L.R.C.S.I., appointed Medical Superintendent of the District Asylum, Monaghan, vice Dr. C. Norman.

Whitn, F. S., M.R.C.S.Eng., L.S.A., appointed Junior Assistant Medical Officer to the Barnwood House Hospital for the Insane, vice R. D. Ball, M.R.C.S.Eng., decessed.

Medical Howours.-Dr. Bateman, of Norwich, has been elected Foreign Corresponding Member of the Académie de Médecine, mainly in recognition of his researches on Aphasia. Dr. Bateman's work, a second edition of which is in preparation, was favourably introduced to the notice of the Academie by Broca, and to that of the Institute of France by Baron Larrey. 